\title{
TOŻSAMOŚCI ROZMYTE. TOŻSAMOŚĆ KULTUROWA POGRANICZA POLSKO-NIEMIECKIEGO W XXI WIEKU. ZARYS PROBLEMÓW
}

\author{
FUZZY IDENTITIES. CULTURAL IDENTITY \\ OF THE POLISH-GERMAN BORDERLAND \\ IN THE 21ST CENTURY: AN OUTLINE
}

\begin{abstract}
This text is an attempt to summarize the three decades (19892019) of NGO activity in the broadly understood Polish-German borderland, with a particular emphasis on the area of the so-called Central Nadodrze. Two organizations, The Society of Witnica's Friends and the daughter organization of the Polish-German Educatio Association "Pro Europa Viadrina," were chosen as an exemplification of a certain way of coping with cultural reality, also in the historical aspect in the border area.
\end{abstract}

Key words: fuzzy identities; cultural identity; Polish-German borderland in the 21 st century

\section{Streszczenie}

Niniejszy tekst stanowi próbę podsumowania trzech dekad (1989-2019) działalności organizacji pozarządowych na szeroko rozumianym pograniczu polsko-niemieckim, ze szczególnym uwzględnieniem obszaru tzw. Środkowego Nadodrza. Jako egzemplifikację pewnego sposobu radzenia sobie z rzeczywistością kulturową, również w aspekcie historycznym na obszarze pogranicza, wybrano Towarzystwo Przyjaciół Witnicy oraz organizację-córkę Polsko-Niemieckie Stowarzyszenie Educatio „Pro Europa Viadrina". Autor zarysował problematykę tzw. tożsamości rozmytych jako odmianę tożsamości kulturowej pogranicza polsko-niemieckiego $w$ XXI wieku.

Słowa kluczowe: tożsamości rozmyte; tożsamość kulturowa; pogranicze polsko-niemieckie w XXI wieku

MACIEJ J. DUDZIAK Akademia im. Jakuba z Paradyża w Gorzowie Wielkopolskim E-mail: mdudziak@ajp.edu.pl http://orcid.org/0000-0001-9094-1397

CITATION: Dudziak, M. J. (2020) Tożsamości rozmyte: Tożsamość kulturowa pogranicza polsko-niemieckiego w XXI wieku: Zarys problemów. Sprawy Narodowościowe:

Seria nowa, 2020(52), Article 2376. https://doi.org/10.11649/sn.2376

This work was supported by the author's own resources. No competing interests have been declared.

This is an Open Access article distributed under the terms of the Creative Commons Attribution 3.0 PL License (creativecommons.org/licenses/by/3.0/pl/), which permits redistribution, commercial and non-commercial, provided that the article is properly cited. (C) The Author(s) 2020

Publisher: Institute of Slavic Studies, Polish Academy of Sciences

Publishing History: Received 2020-08-20; Accepted 2020-12-13; Published 2020-12-23 


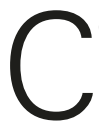
elem niniejszego tekstu jest próba podsumowania trzech dekad (1989-2019) działalności organizacji pozarządowych na szeroko rozumianym pograniczu polsko-niemieckim, ze szczególnym uwzględnieniem obszaru tzw. Środkowego Nadodrza. Jako egzemplifikację pewnego sposobu radzenia sobie z rzeczywistością kulturową, również w aspekcie historycznym na obszarze pogranicza, wybrano Towarzystwo Przyjaciół Witnicy oraz organizację-córkę, Polsko-Niemieckie Stowarzyszenie Educatio „Pro Europa Viadrina”.

\section{KOLONIZACJA ZIEM ZACHODNICH, CZYLI "MYŚMY TU PRZYSZLI" CZY "POWRÓCILI"?}

W miejscowości Lemierzyce, w lesie, na trasie prowadzącej wprost do Kostrzyna nad Odrą i dalej drogą landową do Berlina, dość łatwo odszukać można jedenastometrowy w obwodzie głaz narzutowy. W czasach niezwykłej popularności kanclerza Bismarcka nazwano go oficjalnie Bismarckstein, czyli Kamień Bismarcka. Jednakże do 1945 roku miejscowi nazywali głaz Moritzstein, czyli Kamień Maurycego, na cześć Johana Moritza von Nassau, joannickiego baliwa z pobliskiego Słońska, który nie skąpił środków na remont zniszczonej przez pożar lemierzyckiej świątyni. Kiedy w lutym 1945 roku, w ślad za II Armią WP, pojawili się tu pierwsi polscy kolonizatorzy wojskowi, w ramach oswajania nowego terytorium postanowiono zaopatrzyć głaz w inskrypcję z chwytliwym hasłem propagandowym: "Myśmy tu nie przyszli, myśmy tu wrócili”, z dolną inskrypcją „Lemierzyce 1945" (por. Czarnuch, 2013, s. 64).

Lemierzycki głaz wprost i metaforycznie egzemplifikuje dwa porządki tożsamościowe obecne na tak zwanych Ziemiach Zachodnich: z jednej strony pamięć o lokalnym wydarzeniu, jakim było uhonorowanie pamięci darczyńcy miejscowej ludności do roku 1945, z drugiej zaś spolonizowanie i nadbudowanie treścią kolonizacyjną w ramach repatriacyjnej narracji. Warto zaznaczyć, iż do kolonizowania terenów odebranych III Rzeszy po II wojnie światowej, zwłaszcza w bezpośrednim sąsiedztwie granicy na Odrze, użyto zdemobilizowanych żołnierzy Ludowego Wojska Polskiego, jako „zaprawionych w bojach z niemczyzną żywego muru" (Buławski, 1945, s. 3), a sposób, w jaki peerelowska propaganda narzuciła postrzeganie terenów Ziem Zachodnich, znajduje swoje przełożenie również na dzisiejsze (bieżące) postrzeganie tej rzeczywistości.

Tekst niniejszy stanowi próbę podsumowania trzech dekad funkcjonowania stowarzyszeń mających swoje siedziby na pograniczu polsko-niemieckim, które w różny sposób i z różną intensywnością zmagały się z odkrywaniem, ale również intencjonalnym kreowaniem niezwykle złożonej tożsamości kulturowej pogranicza w jego środkowej części, jako istotnego elementu intencjonalnego kreowania tożsamości lokalnej w szczególnej sytuacji nowego pogranicza. Należy zaznaczyć, że problemy zarysowane poniżej stanowią regionalną i lokalną mutację znacznie szerszych procesów kulturowych mających miejsce w Europie.

\section{WIELOKULTUROWOŚĆ I HOMOGENIZACJA}

Początek XXI wieku to rzeczywistość zglobalizowanego lęku i produkcji lęku na skalę do tej pory nie znaną, w której już nic nie jest oczywiste (Dudziak \& Pomieciński, 2020, s. 5). Wiek XXI, a zwłaszcza jego druga dekada, jest okresem licznych i dynamicznych zmian kulturowo-społecznych w Europie oraz na innych kontynentach. Ruchy migracyjne powo- 
dowane między innymi ucieczką przed wojną oraz innymi zagrożeniami natury egzystencjalnej pociągają za sobą skutki nienotowane w Europie, a zwłaszcza w Polsce od końca II wojny światowej. Efektem wspomnianych procesów migracyjnych jest zupełna zmiana składu etniczno-kulturowego Polski zwłaszcza pod koniec drugiej dekady XXI wieku. Dostrzegalny jest brak jakiegokolwiek przygotowania systemów edukacyjnych $\mathrm{i}$ instytucjonalnych do edukacji wielokulturowej, bazujących na apriorycznym założeniu homogeniczności etnicznej, jako spetryfikowanego stanu Polski wypracowanego w latach sześćdziesiątych XX wieku w PRL Zauważalne jest traktowanie przybyszów w kategoriach „inny”, „obcy”, „egzotyczni". Gorzów i aglomeracja gorzowska, będąc największym miastem w stosunku do globalnej metropolii Berlina, jest „narażony” na pierwszy kontakt z rzeczywistością wielokulturową, lecz nie ma programu inkluzji kulturowej rozumianej przede wszystkim jako diagnoza poznawcza „innych” osiedlających się na terenie miasta i aglomeracji.

Doświadczenia krajów realizujących od dekad politykę migracyjną na poziomie rozwiązań instytucjonalnych, w tym edukacyjnych, pokazują, jak niezwykle czujne i wrażliwe winny być instytucje społeczne, a tym samym wspólnoty, na zmieniającą się rzeczywistość z monoetnicznego składu na reprezentacje o charakterze wieloetnicznym, a przede wszystkim wielokulturowym. Proces edukacji nie może przybierać charakteru zaciekawienia egzotyką czy folklorem, ale winien zmierzać w kierunku poznania w celu akceptacji różnorodności (ataki terrorystyczne ufundowane na gruncie nienawiści w miejscach uważanych „za spokojne” ukazują nazbyt mocno realność problemu zaniechania - np.: Utoya, Berlin, Christchurch, Gdańsk - przy zestawieniu z rodzącymi się na gruncie Gorzowa przejawami nienawiści ufundowanej na niewiedzy - Sklep Ukrainczoka, luty 2018).

Z perspektywy dzisiejszych studiów nad kulturą, a zwłaszcza kultur pogranicza, wyraźny jest znaczący brak refleksji nad kondycją kulturową pogranicza polsko-niemieckiego w kontekście przemian w Europie w nawiązaniu choćby do przekrojowych i fundamentalnych prac zbiorowych z okresów wcześniejszych lat 1945-1970 (zob. Kwilecki, 1970, s. 8) oraz 1990-2000 (zob. Mazur, 1997, s. 13). Trudność ta wynika z kilku nakładających się na siebie elementów:

1. Problem natury metodologiczno-ontologicznej oznaczający w tym przypadku, jak definiować kulturę, która wymyka się konwencjom skonstruowanym jeszcze w XIX wieku, a znacząco wypełniony treścią w wieku XX. O ile bowiem tradycyjnie pojmowane nauki o kulturze dość zręcznie opisywały tradycyjne wspólnoty etniczne proste, czy to w warunkach pozaeuropejskich, czy też europejskich (społeczności chłopskie), o tyle brakuje współcześnie narzędzi językowych do adekwatnej interpretacji współczesnych zmian kulturowych. Osobnym elementem jest zmiana i wpływ zmian w zakresie procesów spoteczno-kulturowych w Polsce i innych krajach Europy Środkowej i Wschodniej wynikające z końca epoki komunizmu i realnego socjalizmu (zob. Buchowski, 2001, s. 5).

2. Kolejnym istotnym elementem jest przeświadczenie o zamknięciu tej tematyki badawczej wraz z rewitalizacją całej lawiny prac i badań poświęconych dziedzictwu kulturowemu Ziem Zachodnich i Północnych, które szczyt swojej intensywności miały w latach dziewięćdziesiątych XX wieku, a które wyraźnie zaczynają zanikać wraz z wejściem Polski do Unii Europejskiej w roku 2004 (Mazur, 1997).

3. Badania w zakresie tożsamości kulturowej pogranicza polsko-niemieckiego rozumianej w ujęciu antropologicznym, czy też szerzej w perspektywie studiów nad kulturą, de facto nie było nigdy prowadzone. Nie mam oczywiście na myśli kompetentnych opracowań studiów nad grupami etnicznymi wyodrębnionymi (Łemkowie, Ukraińcy, Romowie), ale studiów nad społecznościami jako takimi. Zwłaszcza w wieku XXI i zwłaszcza w kon- 
tekście silnych ruchów migracyjnych bez rozpatrywania ich w kategoriach zarobkowych, przygranicznych.

4. Brak jest jakichkolwiek badań dotyczących współczesnej kondycji pogranicza. O ile publikacji zaliczanych do historii miejsca, regionu pogranicznego traktowanych $w$ tradycyjny sposób uprawiania nauki wskazać można wiele, o tyle w zakresie odpowiedzi na pytanie: jak pogranicze staje się wspólnotą o charakterze wyspowym (Burszta, 2000) odpowiedzi brakuje zupełnie.

5. Nie podlegają obserwacji takie procesy jak osadnictwo niemieckie po polskiej stronie (szczególna koncentracja następuje w okolicach Gorzowa w miejscowości Rybakowo), ale również po niemieckiej stronie: to jest Frankfurt, Manschow i Falkenhagen. Problem braku badań prawdopodobnie wynika z braku narzędzi do rejestrowania przepływu ludności wynikającego z postanowień Układu z Schengen o swobodnym przemieszczaniu się i osiedlaniu.

Na powyższe ustalenia nakładają się dodatkowo dwa kolejne elementy

- Tzw. Ziemie Zachodnie były obszarem w zamyśle komunistów, na którym miał zostać zrealizowany projekt inżynierii społecznej polegający między innymi na „wyhodowaniu" nowego socjalistycznego człowieka, o których wspomniany już w tym tekście Rajmund Buławski pisał tak:

Selekcja osób, które pójdą na nowe tereny będzie musiała być prowadzona pod kątem widzenia wyłowienia najtęższych sił i to nie tylko, o ile będzie chodziło o szerokie warstwy włościan oraz robotników rolnych i przemysłowych, lecz także innych grup społecznych, a [...] znaczenie będzie miał właściwy dobór [...] elementu imigracyjnego. [...] Tworząc na prastarych ziemiach słowiańskich nowe życie powinniśmy mu dać zdrowe podstawy biologiczne. Toteż muszą być spośród osób zgłaszających się do wyjazdu na zachód bezwzględnie wyeliminowane jednostki obciążone chorobami i ułomnościami dziedzicznymi, zwłaszcza umysłowymi (Buławski, 1970, ss. 52-54).

- Obszar Ziem Zachodnich był w konsekwencji „projektu kolonizacyjnego” realizowanego przez PRL do roku 1970 (dopiero w latach 50. znika z literatury ten termin na rzecz terminu "osadnictwo") obszarem wielokulturowym, przy czym socjalizm powiązał termin „kultura” z terminem „naród” (bądź grupy etnograficzne lub etniczne: Ukraińcy, Łemkowie, Romowie etc.), pozbawiając tym samym zróżnicowane kulturowo grupy kolonizatorów kultury i nadając im kulturę socjalistyczną - narodową (ten proces dzieje się do dziś).

\section{TOŻSAMOŚCI ROZMYTE}

Eric Hobsbawm stwierdził w pracy Invention of Tradition, iż im odleglejsza i bardziej wygasła jest przeszłość, tym swobodniej można się nią posługiwać do celów czysto symbolicznej mobilizacji (Hobsbawm \& Ranger, 1993). Takie podejście oznacza, iż przeszłością można „dowolnie” manipulować, tzn. używać dowolnych kombinacji i zestawień służących lepszej i pełniejszej relacji z własną "małą ojczyzną" funkcjonującą w ramach pogranicza polsko-niemieckiego.

Interpretacja kultury jako rzeczywistości wszechogarniającej i determinującej wspólnotowe i indywidualne strategie radzenia sobie w rzeczywistości przypomina proces tworzenia wielkich dzieł malarskich, a w zasadzie chodzi tu bardziej o metodologię i technike ich tworzenia, etapy prac schowane przez setki lat przed okiem publiki. Badania różnorodny- 
mi technikami XXI wieku ukazują dopiero właściwą złożoność i stopień skomplikowania. Przy czym nie chodzi bynajmniej o rozmycie pierwotnych kształtów kultury, ale o stałą kondycję rozmycia, konstrukt taki zawsze pozostanie potencjalnie gotowy do nakładania kolejnych warstw, zmian kształtu zasadniczych figur, zaś magazyny kulturowych imponderabiliów mają różną zawartość, bez wskazywania rodowodu innego niż lokalny.

Termin „tożsamość" nastręcza ogromne trudności definicyjne, co przy równoczesnym kryzysie tożsamościowym (z jednej strony) i renesansie popnacjonalizmu (z drugiej), czy też bardziej zmianie XX-wiecznych wartości o charakterze podstawowym niesie za sobą niepewność co do rzeczywistego definiowania pojęć. Konstruowanie nowej tożsamości kulturowej na omawianym terenie opiera się z reguły na następującym schemacie:

a. "wyprowadzenie z mroku” historii niemieckich elementów związanych z poszczególnymi miejscowościami (np.: Kostrzyn nad Odrą - Fryderyk II, Dąbroszyn - Hans Adam von Schőning, Gorzów - Max Bahr),

b. utrwalenie i rozpowszechnienie wiedzy w postaci form zwartych,

c. nadawanie prezentowanej historii lokalnego kontekstu, bez wyraźnej korelacji z etnicznością oraz

d. o ile to możliwe, nadawanie lokalności perspektywy europejskiej według hasła: Niemcy wybudowali miasta, Holendrzy uregulowali bieg Odry i Warty, Francuzi i Włosi nadali architektonicznego splendoru pałacom i dworom, Polacy rozwijają pozostawione dziedzictwo.

Na ziemi lubuskiej problem kulturowej tożsamości był i jest skomplikowany. Zarówno zwykłe ludzkie poczucie przyzwoitości, jak i zasady intelektualnej rzetelności były w sprzeczności z powszechną na tym terenie praktyką pomijania siedemsetletniej obecności Niemców i przemilczania dramatycznych okoliczności wymiany ludności połączonej ze zmianą kultury dokonanej tu w roku 1945. Zaistniałe polityczne warunki ułatwiły wielu gorzowianom usunięcie tego poznawczego dysonansu, który Werner Bader - szef LBMB w latach dziewięćdziesiątych XX wieku określał, z ironią nie pozbawioną słuszności, słowami: Polacy posiedli niezwykłą umiejętność mówienia o siedmiu stuleciach historii Nowej Marchii bez użycia słowa „Niemiec” (Bader, 2013, s. 278).

To właśnie ruchy oddolne, zorganizowane w formie towarzystw i stowarzyszeń zajęły się krótko przed 1990 rokiem i z całą mocą po nim badaniem przeszłości, nawiązywaniem relacji z byłymi mieszkańcami, a w konsekwencji intencjonalnym kreowaniem nowej tożsamości kulturowej, którą określam terminem „tożsamość rozmyta”. W tożsamości rozmytej nie chodzi o rozmywanie podstawowych treści kulturowych, które konstruują jej podstawową kondycję, ale o nakładania na siebie różnorodnych warstw, których źródła wypływają z odmiennych od siebie kontekstów kulturowych. W konwekcji rozmycia powstaje szczególna tkanka wielokulturowości o trudnych do uchwycenia w konwencjonalnych ramach poznawczych kształtach. Jednym z przykładów jest Towarzystwo Przyjaciół Witnicy, powstałe jeszcze w roku 1986, oraz będące córką tegoż Polsko-Niemieckie Stowarzyszenie Educatio Pro Europa Viadrina, powstałe w 1997 roku w Dąbroszynie. Zarówno jedna jak i druga organizacja za jedno ze swoich głównych poznawczych wyzwań postawiły sobie zadanie uchwycenia właściwej specyfiki autodefiniowania, które Zbigniew Czarnuch sformułował następująco:

Zupełnie inaczej i bardzo specyficznie proces ten przebiegat w przypadku pojednania tych Polaków i Niemców, którzy ten sam dom, wieś czy miasto określali zaimkami mój, moja, moje. Polaków, którzy w następstwie wywołanej przez Niemców i przegranej przez nich wojny oraz w wyniku przyjętej przez polityków zwycięskich mocarstw koncepcji budowania powojennego europejskiego ładu, zamieszkali w domach stojących na ziemi uznawanej dotąd przez Niemców za swą ojczyznę. Tutaj ten proces polsko-niemieckiego pojednania przebiegał w sposób 
wyjątkowo zawiły, bo emocje ogniskowały się w jednoznacznie określonej konkretnej zagrodzie, domu, warsztacie, wsi czy mieście. U nich - spotęgowane pamięcią doznanej krzywdy wydziedziczenia, pielęgnowanej w organizacjach wypędzonych, u nas - lękiem przed ich powrotem i utratą dobytku. Po stronie niemieckiej przeszkodą w pojednaniu na tej płaszczyźnie była nadzieja na odzyskanie utraconych dóbr i stron ojczystych, umacniana przez polityków oraz kierownictwo polityczne związku, skupiającego ludzi przekonanych o tymczasowości granic wytyczonych w roku 1945. Po polskiej stronie, w warunkach trwania wyścigu zbrojeń, przeszkodą był polityczny klimat potęgujący świadomość zagrożenia konfliktem zbrojnym z możliwością utracenia swego rodzinnego gniazda (Czarnuch, 2013, s. 55).

W stowarzyszeniu i w stowarzyszaniu się w formule określonej powyżej jest coś głębszego niźli jedynie próba odtworzenia w części lub całości świata wspólnoty utraconej, swoiście pojmowanego powrotu do Edenu. Jest to wewnątrzkonstytucyjne pragnienie budowania i kreacji świata na nowo, ustalania reguł gry od początku i na własnych zasadach. W określaniu zbioru zasad i relacji, w układzie sił pomiędzy rządzącymi a rządzonymi. Materia i stopień skomplikowania społeczeństwa w rozumieniu Gesellschaft jest tak duża, iż poza ideologiami totalizującymi i totalitarnymi dający ułude rozwiązania powszechnego, że mikroukłady, jakimi są stowarzyszenia, dają chwilową ulgę. Te wyczerpały swoją żywotność symbolicznie w roku 2019 (choć do końca roku można było swobodnie przekraczać granicę) sprowadzając ją do poziomu regionalizmu.

Tożsamość kulturowa, w ujęciu antropologicznym, czy też szerzej w kontekście nauk o kulturze, jest pojęciem niezmiernie szerokim, o wielu płaszczyznach i wymiarach. Niemniej jednak sam termin, jak i jego pochodne stanowią jeden z podstawowych kierunków eksploracji współczesnej humanistyki. Więcej, współcześnie powstają podstawowe dylematy i problemy natury epistemologicznej i terminologicznej: o ile świat był relatywnie statyczny w przeszłości, a przynajmniej tak zdawało się przy próbach jego uchwycenia tak zwanym opisem naukowym to w XXI wieku zmiany są tak dynamiczne, że trudno, nawet przy respektowaniu i wiadomości ukutej przez Clifforda Geertza „after the fact” żywić nadzieję o jego adekwatności. Uprawiamy opis narzędziami z wieku XIX wzmocnionego jedynie wiekiem XX, stąd takie pojęcie jak tożsamość kulturowa jest czymś znacznie szerszym niźli tylko zjawisko tożsamości połączonej z etnicznością. Wiek XX, który w imię ideologii w znaczącym stopniu dokonał procesu anihilacji społeczności prostych i chtopskich na rzecz projektów inżynierii społecznej o charakterze homogenicznym, upłynął pod znakiem kolonizacji i postkolonizacji, w tym również w kontekście, tak zwanych Ziem Zachodnich. Rozpatrując powyższe zagadnienia w kontekście należy zwrócić uwagę na samą nazwę Środkowego Nadodrza, która swoje źródło ma pod drugiej stronie granicy.

Określona cezura czasowa zdefiniowana w okresie pomiędzy 1989 a 2019 rokiem (symboliczne zamknięcie granic uwarunkowane COVID-19), różnorodne próby konstruowania i inspirowania kreacji intencjonalnej tożsamości: z jednej strony budowanie tożsamości lokalnej, z drugiej zaś na drugim planie, choć wciąż żywotne tożsamości narodowe. Zasadniczy zwrot nastąpił wraz z wejściem Polski do UE oraz i przede wszystkim do Strefy Schengen, gdzie wytworzyło się, w zupełnym oderwaniu od intencji refleksyjnego założenia bycia na pograniczu, spontaniczne wytwarzanie odmiennej tożsamości bazującej na bezpośrednim doświadczeniu. Dotyczy to zarówno Niemców, jak i Polaków, choć oczywiście przewaga leży po stronie polskiej. COVID-19 uświadomił skalę tego problemu, który zasadniczo można podzielić na następujące grupy:

1. Polacy mieszkający na stałe po polskiej stronie, a pracujący po drugiej stronie,

2. Polacy mieszkający na stałe po niemieckiej stronie i dojeżdżający do pracy po polskiej stronie, 
3. Polacy mieszkający i pracujący po niemieckiej stronie, ale w bezpośredniej bliskości granicy,

4. Niemcy mieszkający po niemieckiej stronie, ale pracujący po polskiej,

5. Niemcy mieszkający po polskiej stronie, i pracujący po niemieckiej.

Ważnym elementem jest to, że istnienie stowarzyszenia dało impuls do relacji i inspiracji do innych podmiotów i stowarzyszeń tworzących niejednorodną, ale spowinowaconą sieć (na szczególną uwagę po niemieckiej stronie zasługuje Zamek Trebnitz Centrum Edukacji i Spotkań), zaś po polskiej towarzystwa z Sulęcina, Międzyrzecza, Słońska oraz Chojny, które wymagają odrębnego opracowania.

Przywołajmy raz jeszcze słowa Zbigniewa Czarnucha:

W poszukiwaniu swej tożsamości budowanej na rzetelnej wiedzy miasto zrezygnowało z obchodów Dnia Wyzwolenia, za który od roku 1945 uznawano dzień wkroczenia do niego oddziatów Armii Czerwonej. Wtedy ziemie te nie należały jeszcze do Polski, bowiem był to obszar strefy okupacyjnej Niemiec. Wyzwolenie dotyczyło tylko polskich jeńców wojennych i przymusowych robotników. Był to jednak dzień w dziejach miasta przełomowy. Od roku 1995 obchodzony jest wspólnie z przedstawicielami BAG jako „Dzień Pamięci i Pojednania". Składane są wtedy wieńce przy kamieniu upamiętniającym miejsce dawnego niemieckiego cmentarza zamienionego na Park Kopernika oraz pod pomnikiem na Cmentarzu Wojennym. Od roku 2008 podczas tych obchodów uderza się także w Dzwon Pokoju [...] Ruchy te, skierowane na przyjazne współdziałanie w dziele opieki nad niemiecką spuścizną kulturową, zazwyczaj były inicjatywami ziomkowskimi, choć w Słońsku wobec joannitów, a w Witnicy wobec wysiedlonych impuls nawiązania współdziałania wyszedł od strony polskiej. Były jednak miasta, w których nawet w latach 90. ani później nie doszło do oficjalnej, stałej i żywej współpracy organizacji ziomkowskiej z władzami miasta, jak to miało miejsce w Kostrzynie, Drezdenku, Dobiegniewie czy Strzelcach Krajeńskich. Na ogół było to pochodną braku w tych środowiskach sprawnych i przekonanych do sprawy przywódców i organizatorów, potrafiących temu zadaniu sprostać (Czarnuch, 2013, s. 26).

Wybrana cezura czasowa niniejszego tekstu, to jest lata 1989-2019, nie jest li tylko symboliczną formułą temporalnego mierzenia czasu. Zmiany zachodzące w obszarze transgranicza pozostają w ścistym związku z obserwowalną radykalizacją i fundamentalizacją bezrefleksyjnych postaw i procesów nacjonalistycznych mających miejsce w Polsce oraz Europie. W 2017 roku całą Polskę i Niemcy obiegła informacja o zastrzeleniu w okolicach niemieckiego Lebus (od tej miejscowości nazwę nosi cały region administracyjny po polskiej stronie) żubra, który postanowił przenieść się z polskiej na niemiecką stronę. Niefortunna sytuacja rozpętała burzę informacyjną sprowadzającą się do następującego mianownika przedstawionego w reportażu Renate Meinhof zamieszczonym w "Sueddeutsche Zeitung”: „Po drugiej stronie, dokładnie naprzeciw miasteczka Lebus nad Odrą, w środku wału przeciwpowodziowego stoi transparent z jasnego płótna. [...],Żubr jest zwierzęciem objętym ochroną' - głosi tekst po niemiecku, a na samym dole widnieje napis "mordercy'". Z wydarzenia na pozór codziennego, które zakwalifikować można, jako niefortunny i nierozważny krok przedstawicieli lokalnych władz, w konsekwencji uczyniono emblematyczny symbol relacji polsko-niemieckich ufundowanych na konflikcie.

Do pejzażu relacji wynikających ze zmagań dwóch wizji świata dołożyć należy miejsce-symbol ulokowany w Witnicy - miasteczku leżącym kilkanaście kilometrów od granicy polsko-niemieckiej. Od początku zmian polityczno-społecznych, to jest od roku 1990, niezwykłą funkcję edukacyjną, a również badawczą pełnił obiekt nazywany "Żółtym Pałacykiem", w którym obok Izby Regionalnej, stanowiącej muzeum wiedzy o byłych i obecnych mieszkańcach tego obszaru przygranicznego, o trudnych losach mieszkańców uwikłanych w tryby historii, mieściło się Centrum Współpracy Polsko-Niemieckiej, prowadzonej w du- 
chu dialogu. Efektem zmian w zakresie specyficznie rozumianej polityki lokalnej była stopniowa choć szybka degradacja funkcji centrum współpracy polsko-niemieckiej na rzecz powstania i rozwijania paramilitarnego oddziału dzieci i młodzieży, która została zainstalowana przez nowe władze samorządowe. W reportażu telewizji RBB z 2018 roku prezentującym działalność tej organizacji, która swoje statutowe cele działalności określa przede wszystkim jako: działanie na rzecz niepodległości Rzeczypospolitej i jej umacniania, wychowanie członków Związku w duchu patriotycznym i państwowo-twórczym oraz przygotowanie młodzieży do służby wojskowej i obrony cywilnej jej lokalny przywódca powiada wprost: „Polska dla Polaków, Niemcy dla Niemiec, Syria dla Syryjczyków”. Paradoksalnie, wydana w 2009 roku książka Budujemy mosty inspirowana działalnością Centrum Współpracy Polsko-Niemieckiej stanowi w swojej wymowie dokładne zaprzeczenie nacjonalistycznej ideologii wcielanej w życie przez nowych depozytariuszy "Żółtego Pałacyku".

Latem 2018 roku lokalne władze odmówity po raz pierwszy bez podania powodu organizacji corocznych uroczystych urodzin kierowanych przede wszystkim do społeczności lokalnej Jucie von der Lencken, wdowie ostatniego niemieckiego właściciela pałacu w Dąbroszynie, które nieprzerwanie organizowane były od końca XX wieku. I niech tych kilka przykładów stanowi podsumowanie niniejszego tekstu.

\section{BIBLIOGRAFIA}

Bader, W. (2013). Pierwsze oficjalne wyprawy organizacji ziomkowskich na Ziemię Lubuską. W Z. Czarnuch (Red.), Samozwańcze konsulaty: Rzecz o emocjonalnym stosunku Niemców i Polaków do tego samego skrawka ziemi (ss. 277-287). Polsko-Niemieckie Stowarzyszenie Educatio Pro Europa Viadrina; Towarzystwo Przyjaciół Archiwum i Pamiątek Przeszłości.

Bauman, Z. (2006). Społeczeństwo w stanie oblężenia (J. Margański, Tłum.). Sic!

Bauman, Z. (2018). Retrotopia: Jak rządzi nami przeszłość. Wydawnictwo Naukowe PWN. Buchowski, M. (2001). Rethinking transformation: An anthropological perspective on post-socialism. Wydawnictwo Fundacji Humaniora.

Buławski, R. (1945). I Sesja Rady Naukowej dla Zagadnień Ziem Odzyskanych, 30.71.8.1945 r.: Z. 2. Problemy osadniczo-przesiedleńcze Ziem Odzyskanych. Biuro Studiów Osadniczo-Przesiedleńczych.

Buławski, R. (1970). Niektóre problemy polityki osadniczej. W A. Kwilecki (Red.), Ziemie Zachodnie w polskiej literaturze socjologicznej: Wybór tekstów (ss. 50-74). Instytut Zachodni.

Burszta, W. J. (1994). Yes: Nostalgiczne strefy pamięci. Konteksty: Polska Sztuka Ludowa, 48(1-2), 54-57.

Burszta, W. J. (Red.). (2000). Euroregion "Pro Europa Viadrina” mostem do Zjednoczonej Europy: Analizy i rozpoznania. Wydawnictwo Stowarzyszenia Gmin Polskich Euroregionu „Pro Europa Viadrina”.

Czarnuch, Z. (2000). Po tej stronie Odry (R. Wawrzyniak, Tłum.). Towarzystwo Przyjaciół Archiwum i Pamiątek Przeszłości.

Czarnuch, Z. (Red.). (2013). Samozwańcze konsulaty: Rzecz o emocjonalnym stosunku Niemców i Polaków do tego samego skrawka ziemi. Polsko-Niemieckie Stowarzyszenie Educatio Pro Europa Viadrina; Towarzystwo Przyjaciół Archiwum i Pamiątek Przeszłości. 
Dudziak, M. J., \& Pomieciński, A. (2020). Polifem: Szkice z antropologii (nie)oczywistości. Nauka i Innowacje.

Hobsbawm, E., \& Ranger, T. (Red.). (1993). The invention of tradition. Cambridge University Press.

Kwilecki, A. (Red.). (1970). Ziemie Zachodnie w polskiej literaturze socjologicznej: Wybór tekstów. Instytut Zachodni.

Mazur, Z. (Red.). (1997). Wokół niemieckiego dziedzictwa kulturowego na Ziemiach Zachodnich i Pótnocnych. Instytut Zachodni.

Wiegelmann, G. (2006). Alltags- und Festspeisen in Mitteleuropa: Innovationen, Strukturen und Regionen vom späten Mittelalter bis zum 20. Jahrhundert. Waxmann. 